Daniel $L$. Thomton is an assistant vice president at the Federal Reserve Bank of St. Louis. Lynn D. Dietrich provided research assistance.

\title{
Do Government Deficits
}

\section{Matter?}

$\mathrm{T}$ about the size of the federal deficit and the rather modest success of the Gramm-RudmanHollings Act to reduce it. The traditional, that is, Keynesian, view of deficit spending in macroeconomics was that it could smooth out fluctuations in economic activity due to gaps between saving and investment that were primarily the result of exogenous shifts in investment. From this perspective, deficit spending was seen as both desirable and necessary to offset cyclical fluctuations in economic activity that were characteristic of capitalist, free-market economies.

Recent discussions of government deficits, however, have focused on their alleged adverse effects. It is now common to blame deficit spending for high real rates of interest and the large and persistent trade deficit. Moreover, there is widespread concern that large and persistent federal deficits will produce stagnant economic growth and result in renewed inflationary pressures.

An alternative view, called Ricardian equivalence, however, sees deficit spending as a harbinger of neither good nor ill. According to this view, deficit spending cannot offset fluctuations in economic activity due to exogenous shifts in either private saving or investment; nor, can it be blamed for high real interest rates or the large trade deficit. Moreover, it has no influence on the outlook for economic growth or inflation. Macroeconomic tests of the effects of deficits on the economy using U.S. time-series data have generally favored the Ricardian view. ${ }^{1}$

The purpose of this article is to review both views of deficit spending to determine which view of the relationships between deficit spending and various associated macroeconomic variables is supported by evidence from 16 OECD countries over the period 1975-86..$^{2}$
Fecently, there have been three excellent surveys of the empirical investigations of Ficardian equivalence. See Barro (1987), Bernheim (1987) and Aschauer (1988). Also, see Evans (1988), Koray and Hill (1988) and Leiderman and Razin (1988) for more recent work that is not summarized in the three surveys. For some very recent work on this issue, see Feldstein and Elmendorf (1990), Modigliani and Sterting (1990) and Kormendi and Meguire (1990). Most of the empirical evidence against the Ricardian view is at the microeconomic level using crosssectional or panel data.

2The reader is cautioned that the evidence presented here can be considered suggestive for only a couple of reasons. First, strictly speaking, Ricardian equivalence is a proposition about what happens when deficit spending is substituted for taxes at an unchanged expenditure level. Second, in a rational expectations framework, only unanticipated changes in deficits should affect macroeconomic variables, and there is no plausible way to isolate the unanticipated component of deficits from these annual data. Third, the deficit measures used here are not cyclically adjusted. Hence, they are endogenous, at least in part. 


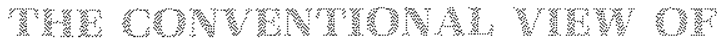

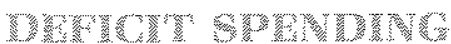

Total saving has two components: public and private saving. Public saving measures the government's surplus or deficit position: surpluses represent positive public saving, while deficits represent public dissaving. In the Keynesian view, deficits can be used to offset gaps between saving and investment, thereby stabilizing output around its potential (full-employment) level. For example, if private saving is too high relative to investment to achieve potential output, a government deficit will reduce the amount of total saving and close the gap between saving and investment. Conversely, if private saving is too low relative to investment, a government surplus can increase total saving. Hence, cyclical swings in economic activity arising from movements in the saving/investment gap can be shortened by changing public saving appropriately to maintain total saving at a level consistent with potential output.

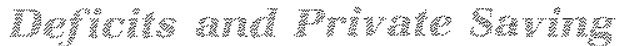

The above analysis is based on the assumption that public and private saving are separate and distinct activities. ${ }^{3}$ In the extreme, they are viewed as totally independent: changes in public saving have no direct effect on private saving and vice versa. ${ }^{4}$ In this case, total saving will change one-for-one with changes in public saving. In the less extreme case, total saving is simply positively correlated with public saving. ${ }^{5}$

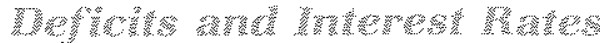

In the conventional view, increases in the deficit cause the interest rate to rise. ${ }^{6}$ Since the

3The following discussion is based on the standard IS/LM aggregate demand-aggregate supply model of the macroeconomy, where deficit spending is treated as exogenous.

${ }^{4}$ Also, deficits can have an indirect effect on saving if the increase in the deficit spending raises real income and, hence, saving. Likewise, if a shift in the saving or investment functions cause a change in income, the deficit will respond endogenousty because both expenditures and taxes are related to the level of income. Hence, the assumption that the series are independent applies to their autonomous components.

sStrictly speaking, the above conclusion holds as long as public and private savings are not perfect substitutes. Note, however, fiscal policy is used to offset changes in private savings, there may be a negative correlation between public and private savings even, if at a more abstract level, the series are unrelated. That is, there may be a policy reaction function where deficits respond, presumably with a lag, to changes in private savings. interest rate is the price of credit, it is determined by the supply and demand for credit. According to the traditional view, an increase in the deficit increases the demand for credit relative to the supply and, consequently, increases the interest rate.

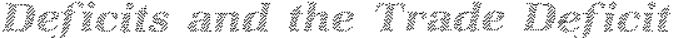

The effect of deficits on credit demand can also affect the relationship between government deficits and the trade deficit. The effect of deficit changes on interest rates depends on the slope of the credit supply curve-the steeper the slope, the larger the effect on interest rates. Among other things, the slope of the credit supply curve depends on the degree of openness of the nation's money and capital markets to the rest of the world. In general, the more open these markets are, the flatter is the supply of credit.

To see this more easily, let's recast the discussion in terms of the demand for securities. In this framework, the price of bonds and, hence, the interest rate are determined by the supply and demand for bonds. The bond and credit markets are related inversely: those who supply credit are demanding bonds while those who demand credit are supplying bonds. If financial markets are open and competitive, the demand curve for bonds seen by individual bond suppliers, including the government, is flat at the market price of securities. In other words, no matter how many bonds that individuals, firms or the government may supply, individually, they see no effect on the market price of bonds and, hence, on the interest rate. All market participants, including the federal government, are

The discussion here abstracts from the possible effects of deficits on the rate of inflation, so the hypothesized effect in this section is on the real interest rate.

7Most standard ISILM aggregate demand-aggregate suppiy models assume that there is no direct effect of the increase in the deficit on private savings; however, this assumption is not necessary to obtain the usual implications. All that is required is that the direct effect on private savings (if the effect is to increase it) be less than the in crease in the deficit. Also, the effect on the interest rate would be small if the monetary authority monetized debt to keep real interest rates tow. While this is a controversial issue, the evidence for the U.S. suggests that the Federal Reserve has not monetized the debt. See Thornton (1984) This discussion abstracts from the effect of the deficit on interest rates via a deficit-induced increase in the rate of inflation. 
Figure 1

Price Level and Output Determination

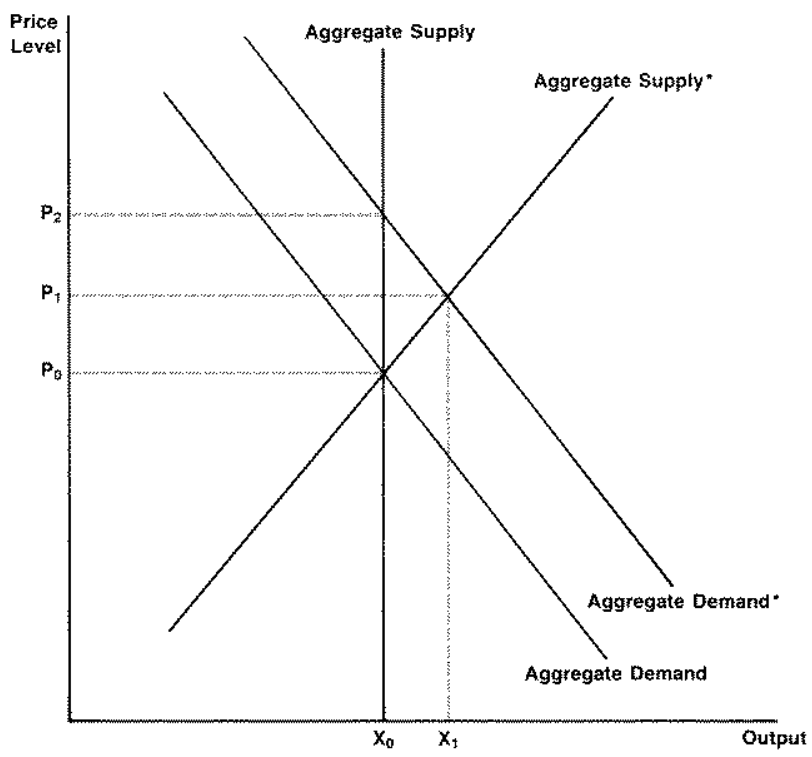

13.7.

"small" relative to the total market, that is, each is a "price-taker." ciently open, the money and capital markets are competitive and the government is a price-taker, changes in deficit spending will have no effect on the interest rate. Increases or decreases in the supply of bonds will be fully absorbed at the current market price.

This does not mean, however, that deficit spending has no effect on the economy. In the above case, the deficit will be matched by foreign claims on U.S. assets. That is, there will be a capital inflow which, given the balance-ofpayments identity, must be matched by a trade deficit. Hence, if the economy is "sufficiently"

BThis argument also applies to the Federal Reserve's con. trol over real interest rates in an open economy, and may have implications for the Fed's control over interest rates in a "closed" economy as well.

9The "long run" tends to mean different things in macroeconomics depending on the context in which it is used. In the present IS/LM aggregate demand-aggregate supply framework, it means the period of time for all wages and prices to adiust to exogenous shocks. If all wages and prices adjust instantaneousiy, the aggregate supply curve would be vertical fof all time periods. Hence, the positively sioped aggregate supply curve in this model results from some "imperfections" which keep wages and prices from adjusting instantaneously io shocks.

10Bernheim (1989) and others call this the neoclassical view. In the neoclassical framework, crowding out necessarily open, there may be no (zero) correlation between government deficits and interest rates, but there may be a positive correlation between the government and trade deficits.

The strength of this correlation depends on the degree of openness of financial markets. If financial markets are only partially open or approximated by the competitive model, the government deficit will be positively correlated with both the interest rate and the trade deficit.

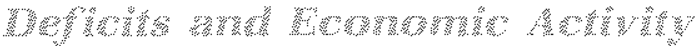

The effect of deficits on economic activity can be illustrated in terms of the aggregate demand/aggregate supply model. The traditional view asserts that increases in the deficit will increase the demand for goods and services, as illustrated in figure 1 . The extent to which the increase in aggregate demand affects output or prices is determined (among other things) by the slope of the aggregate supply curve. The steeper the slope of the aggregate supply curve, the larger the effect on the price level and the smaller the effect on output. If the aggregate supply curve were vertical, the deficit would affect only the price level.

Economic theory and empirical evidence suggest that the aggregate supply curve is upward. sloping in the short run. ${ }^{9}$ If this is true, there should be a positive correlation between deficits and both prices and output.

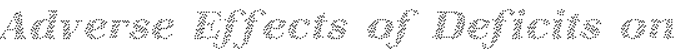

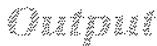

In addition to the positive effects of deficits on output, it is often suggested that deficits can affect output adversely because of their impact on interest rates. In a closed economy, some argue, the deficits raise the real interest rate and, thereby, "crowd out" private investment. ${ }^{10}$

results from a full-employment assumption. The only way that the government can spend more is for the private sector to spend less. That is, interest rates must rise to increase private savings by the amount of the decrease in public savings. The much-hypothesized adverse effects of government deficits in the neoclassical view come either through current government consumption replacing private investment or the assumed lower marginal productivity of public capital (see footnote 11 ). In any event, no explicit distinction between the conventional and neoclassical views is made in the text because they are comparable in their implications (though certainly not with the fullemployment assumptions). 
Other things the same, the degree of crowding out will be larger, the more responsive interest rates are to deficit spending and the more responsive investment spending is to changes in the interest rate. Thus, the larger the effect of deficits on interest rates, the smaller should be the effect on current output. Even with this crowding out effect, however, deficits and output are still expected to be positively correlated-at least in the short run. ${ }^{11}$

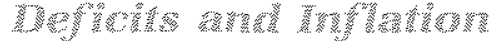

To be confused about the effect of deficits on inflation and the price level is easy; therefore, it is important to understand and recognize the distinction between these effects. The fundamental distinction can best be seen by noting that the price level is measured at a specific point in time, while inflation is measured over an interval. According to the conventional view, an increase in the deficit increases aggregate demand and, hence, the price level. Because adjustments in the price level take place over time, such changes are reflected in the measured rate of inflation during the period of price adjustment. Other things the same, however, prices eventually will adjust to their new higher level after which no further price changes will be forthcoming. Consequently, while deficit spending may affect the price level permanently, it has only a temporary affect on the rate of inflation.
For deficits to really be considered inflationary, they must generate continuing increases in the price level. In terms of the ag. gregate demand and supply curves, deficits would have to cause the aggregate demand curve to keep shifting to the right at a faster rate than the aggregate supply curve. This could happen only if deficits become persistently larger over time, or if they are being monetized (producing increases in the rate of money growth). The dynamic aspect of inflation, however, requires a permanent rise in the rate of money growth in response to the larger deficit. $^{12}$

\section{"Wu

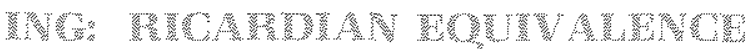

An alternative view of the effects of deficit spending is called Ricardian equivalence. Unlike the Keynesian view, which sees public and private saving as essentially unrelated, the Ricardian view sees them as perfect substitutes. ${ }^{13}$ According to this view, changes in public saving are matched by an equal but opposite change in private saving. This fundamental difference manifests itself in the answer to the question: Is government debt part of society's net wealth?

In the Keynesian view, the answer is "Yes," while the Ricardian alternative would answer "No." According to the Keynesian view, when

\footnotetext{
"Some people fear that deficits could have some longerterm adverse effects due to crowding out. They argue that, if deficits lead to higher interest rates and lower investment, soctety will be left with a smaller capital stock, which, in turn, means that future output will be smaller than it would have been in the absence of deficit-financed expenditures. Consequently, in the short run, deficits and output are expected to be positively correlated. In the long run, however, they may be negatively correlated, or at least negatively correlated with output growth. There is an implicit assumption in this argument about the nature of public expenditures or the relative productivity of "public" and "private ${ }^{t y}$ capital. To see this, note that the supply of output, $Y_{1}$, is a function of labor, $L_{1}$, and the capital stock, $K_{t}$, i.e., $Y_{t}=f\left(L_{i}, K_{t}\right)$.

Output rises with both labor and the stock of capital. Consequently, if a deficit-induced rise in interest rates causes investment to fall in this period, the next period's capital stock will be smaller, as will the next period's output. This assumes that all of the rise in the deficit was used for current consumption. Alternatively, aggregate output could be expressed as a function of labor and the public and private capital stocks, $K^{p s}$, and $K^{p r}$, respectively, i.e., $Y_{t}=h\left(L_{t}, K^{p S}, K^{p P}\right)$. If the rise in the deficit is used to acquire public capital, the immediate effect on output is indeterminant even in the case of complete crowding out, $i . e$. the decline in private capital from what it would have otherwise been is equal to the increase in public capital. See Aschauer (1989a, 1989b).
}

12Deficits can sustain inflation if the monetary authority attempts to peg the nominal interest rate [see Friedman (1968)] or if deficits become explosive. In the latter case, the ratio of interest-bearing government debt to output increases without limit forcing the monetary authority to monetize the debt. See Sargent and Wallace (1981) and Miller and Sargent (1984) for a discussion of these points and McCallum (1984) for a qualification.

${ }^{13}$ This is merely a convenient, equivalent characterization. Ricardian equivalence stems directly from an intertemporal resource constraint. That is, for a given path of expenditures, a cut in present taxes necessarily implies an increase in future taxes of equal present value. If an individual's demand for goods and services depends on his "after tax" net worth-the present value of assets, the present value of liabilities and the present value of taxes-a fall in current taxes would necessarily be matched by an increase in the present value of future taxes. Since a budget deficit merely rearranges the timing of the tax liabilify, is cannot affect aggregate demand. The decrease in public saving (the deficit) must be matched by an increase in private saving.

Strictly speaking, however, Ricardian equivalence holds only for a given path of government expenditures. There can be real effects associated with changing the level or timing of real government expenditures. 


\section{Figure 2}

\section{The Trade Deficit and the Government Deficit}

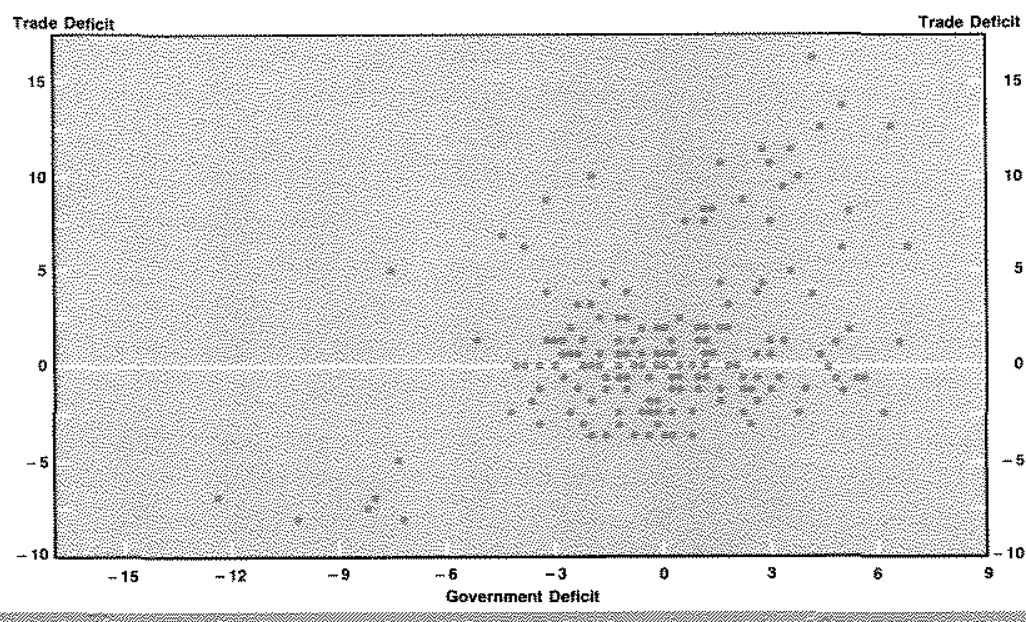

the government issues debt, the holder of the debt views it as an asset; but taxpayers do not view it as their liability. That is, they do not believe that they will have to pay current or future taxes to service or retire the debt. Consequently, their saving behavior is unaffected by the debt issuance.

The Ricardian view, on the other hand, asserts that individuals believe that they, or their heirs, will have to pay taxes to service and re. tire the increased debt. Because they perceive an increase in the present value of their taxes that just offsets deficit-financed expenditures, the stock of government debt is not part of society's net wealth. Hence, a rise in the deficit ta fall in public saving) will be matched by a rise in private saving in anticipation of future taxes.

If public and private saving are perfect substitutes, a decline in public saving-the increase in the deficit-is offset by an increase in private saving, with no effect on the gap between saving and investment. According to this view, then, deficit spending cannot be used to smooth out cyclical variations in economic activity due to exogenous swings in the gap between saving and investment. Moreover, the increased demand for credit due to deficit spending will be matched by an increase in the supply of credit due to an increase in private saving. Also, the increase in aggregate demand that results from a rise in deficit spending will be offset by a decrease in aggregate demand due to the fall in private spending - that is, there is no net change in aggregate demand.

Because the Ricardian view holds that changes in deficit have no net effect on the excess demand for credit or aggregate demand, deficits should be uncorrelated with interest rates, the trade deficit, the price level, output or total saving. Deficits and private saving, however, should be perfectly, positively correlated.

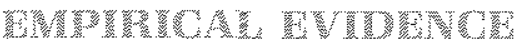

The evidence presented here consists of simple scatter plots between the government deficit and the trade deficit, personal saving, real out put growth, the price level, the inflation rate and the nominal interest rate for $16 \mathrm{OECD}$ countries. ${ }^{14}$ (A more detailed statistical analysis consistent with these scatter plots is presented in the appendix). The currency-denominated variables are expressed as a percent of the country's gross domestic product, GDP, to put them in common units, and all variables are adjusted for their mean values. ${ }^{15}$

Figure 2 shows the relationship between the so-called twin deficits: the trade and the government deficits. The scatter plots show that there

\footnotetext{
14The countries are: Australia, Austria, Belgium, Canada, Finland, France, Greece, Great Britain, West Germany, Ireland, Japan, Norway, Netherlands, Sweden, Switzerland and the United States. The interest rate was not avallable for Austria, Canada, Finland or Greece.
}

15These are pooled time-series cross-sectional data, where the average level is allowed to vary each year. See the appendix for details. 
is a weak (but statistically significant) positive association between the two deficits. This association is consistent with both the conventional view and U.S. time-series data. ${ }^{16}$ Barro (1987), however, finds that the positive association exists for U.S. time-series data only when data for the 1980s are included. This instability is evident for these cross-sectional data as well. When the sample includes only observations for the earlier period, $1975-80$, there is no significant positive relationship between the twin deficits. These data are presented in figures 3 , while data for the later period, 1981-86, are presented in figure 4 . Moreover, further analy. sis suggests that the statistically significant positive relationship does not hold up if other factors are considered (see the appendix).

Figure 5 shows the relationship between personal saving and the government deficit. The strictest form of the conventional view argues that these series should be unrelated, while the Ricardian alternative argues that they should be perfectly, positively correlated. Neither view is supported by these cross-sectional data. Instead, there is a statistically significant negative relationship between these variables. This anomalous result may stem from the response of both the deficit and personal saving relative to GDP to cyclical movements in output. For example, it is well-known that deficits typically rise relative to GDP as output falls and vice versa. If consumers attempt to maintain their living standard in the face of a temporary decline in output, personal saving would fall relative to output. Consequently, personal saving and government deficits relative to GDP should be negatively correlated over the business cycle. In any event, the statistically significant negative relationship supports neither hypothesis. ${ }^{7}$

Figures 6-9 show the relationship between the government deficits and inflation, output growth, the price level and interest rates. In all cases,

15See Barro (1987) and Dewald and Uian (1990). Dewald and Ulan argue that the observed positive association between the iwin deficits in U.S. time-series data results from failing to account for inflation or changes in the market value of the U.S. federal debt or other major elements of the U.S. net external wealth position. This argument, however, requires a different definition of the defict than the one used in the conventional stories of the effecis of deficits on economic variables.

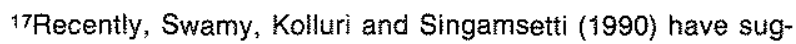
gested that finding any statistically significant relationship between the deficit and interest rates-although the sign of the coefficient is opposite that hypothesized by the con. there is no statistically significant relationship between the deficit and these variables. ${ }^{ \pm}$Consequently, the cross-sectional data provides little or no support for the conventional view. On the other hand, support for the Ricardian alternative is not overwhelming. While the lack of significant relationships between the deficit and interest rates, the trade deficit, output, prices, inflation and economic growth is consistent with the Ricardian view, the lack of a statistically significant positive relationship between the government deficit and private saving is not. Indeed, if deficits and private saving are perfectly, positively correlated because public and private saving are perfect substitutes, a positive relationship between these variables should have been apparent. Thus, at best, the evidence presented here should be interpreted as cautiously favoring the Ricardian view.

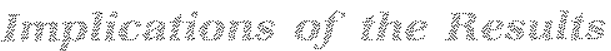

Whether the evidence presented here is taken to support, however cautiously, the Ricardian alternative, the most interesting result is the lack of evidence to support the conventional view. In particular, the evidence suggests that countries with large government deficits do not have higher interest rates or larger trade deficits despite the widespread opinion to the contrary. Of course, these puzzling results could be an artifact of the simple measures of deficit spending used here. If the relationships between government deficits and either interest rates or the trade deficit were as strong as many commentators suggest, however, it is odd that they do not emerge in these annual data across countries. These results, coupled with the fact that more sophisticated empirical studies using U.S. time-series data have also failed to uncover the conventional relationships, should perhaps lead advocates of the conventional view either to rethink their position or present some evidence to support their claims.

ventional view-contradicts the Ricardian equivalence paradigm. Such an extreme view is unwarranted.

18 There are two exceptions when first-differences are used. The one of some importance for the conventional wisdom is the positive and statistically significant relationship between the deficit and output growth, suggesting that larger government deficits have at least some initial positive effect on real output. Of course, if the rise in the deficit is due to an increase in government spending, there is a positive relationship between the deficit and GDP by defintion. See the appendix for details. 
20

Figure 3

The Trade Deficit and the Government Deficit: 1975-1980

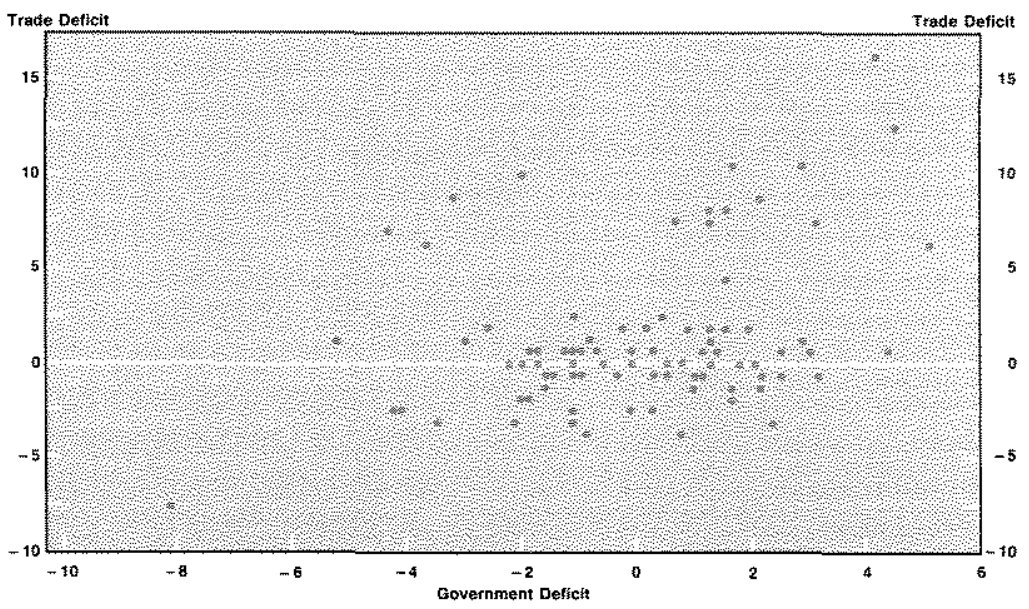

1.

Figure 4

The Trade Deficit and the Government Deficit: 1981-1986

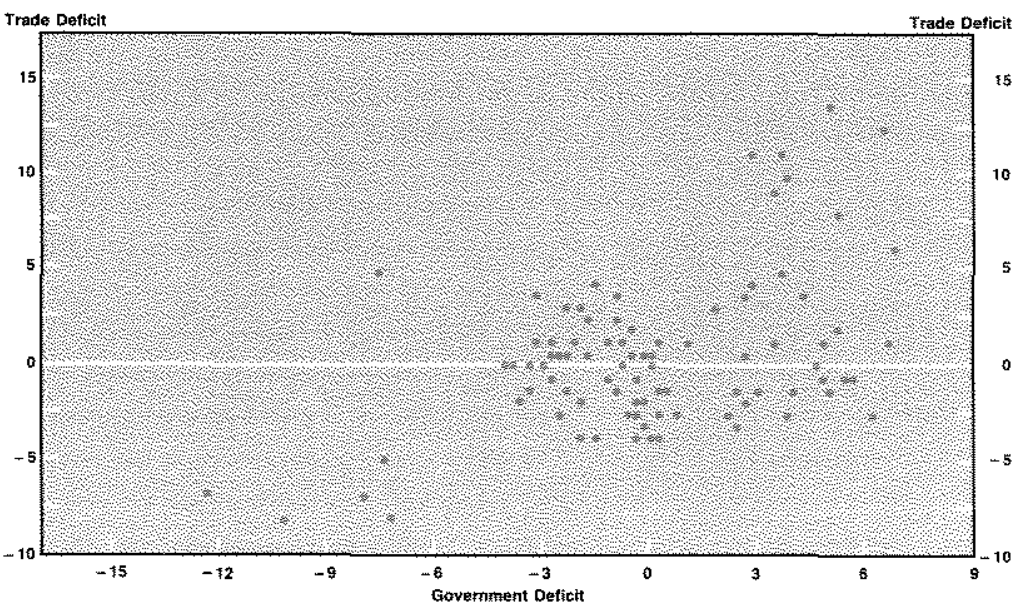

Figure 5

Personal Saving and the Government Deficit

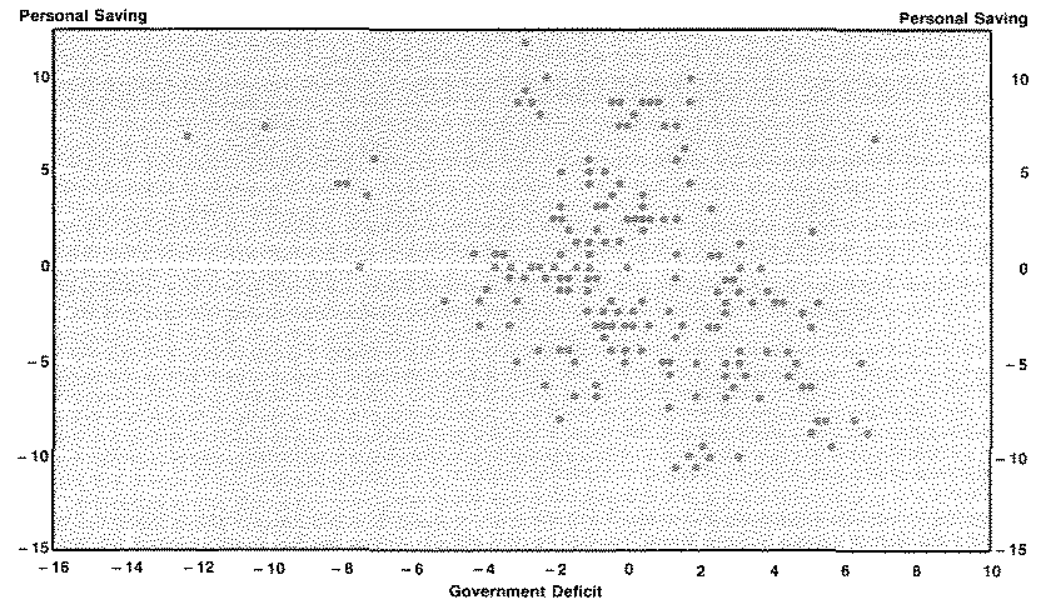




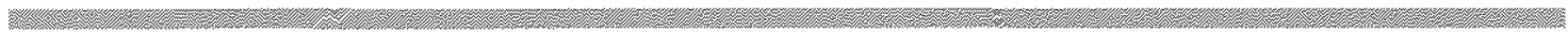

Figure 6

The Rate of Inflation and the Government Deficit

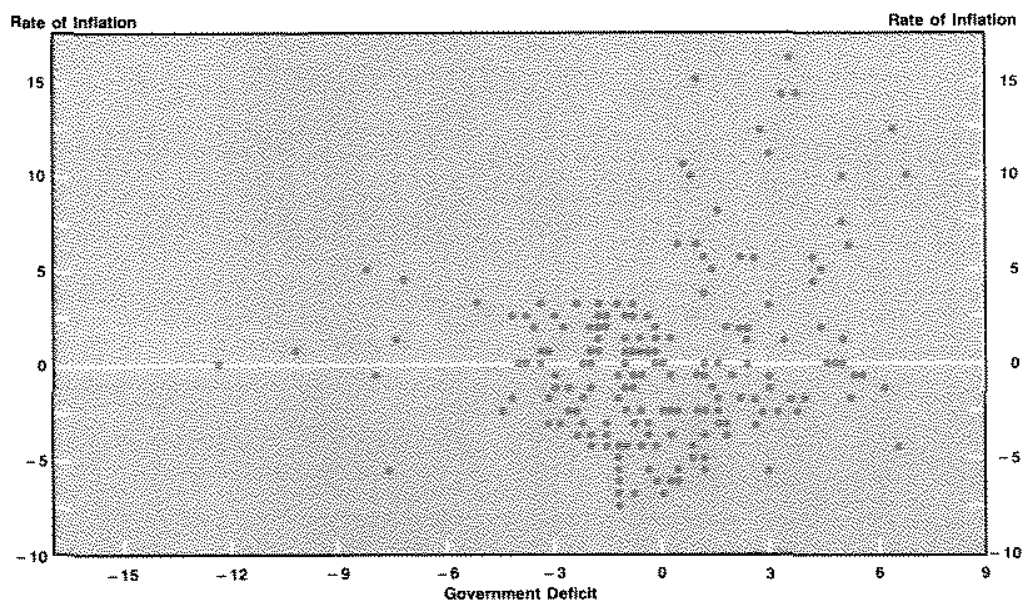

Figure 7

The Growth Rate of Real GDP and the Government Deficit

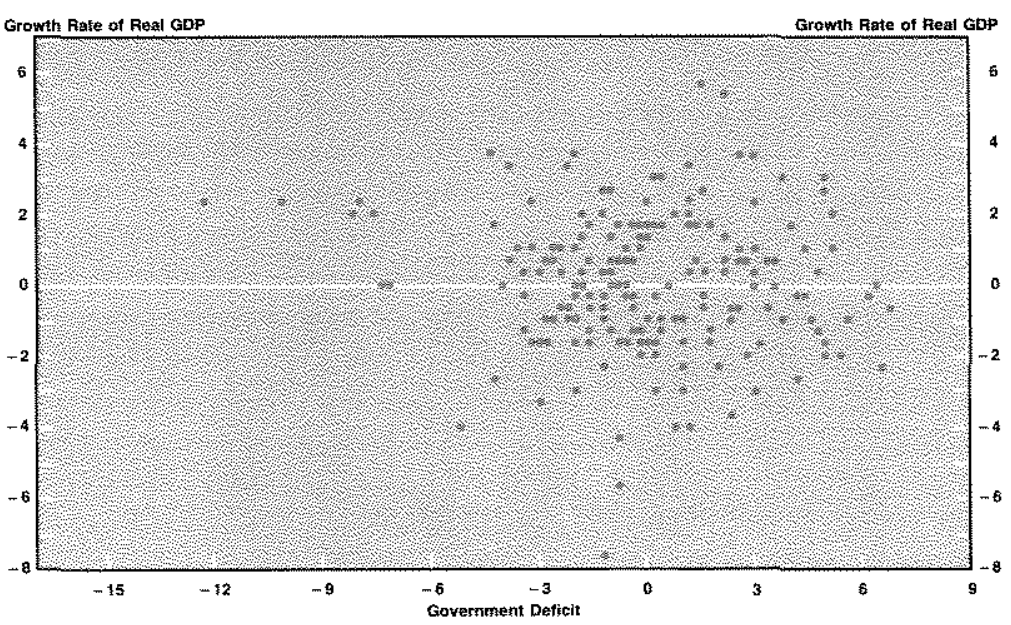

2.

Figure 8

The Price Level and the Government Deficit

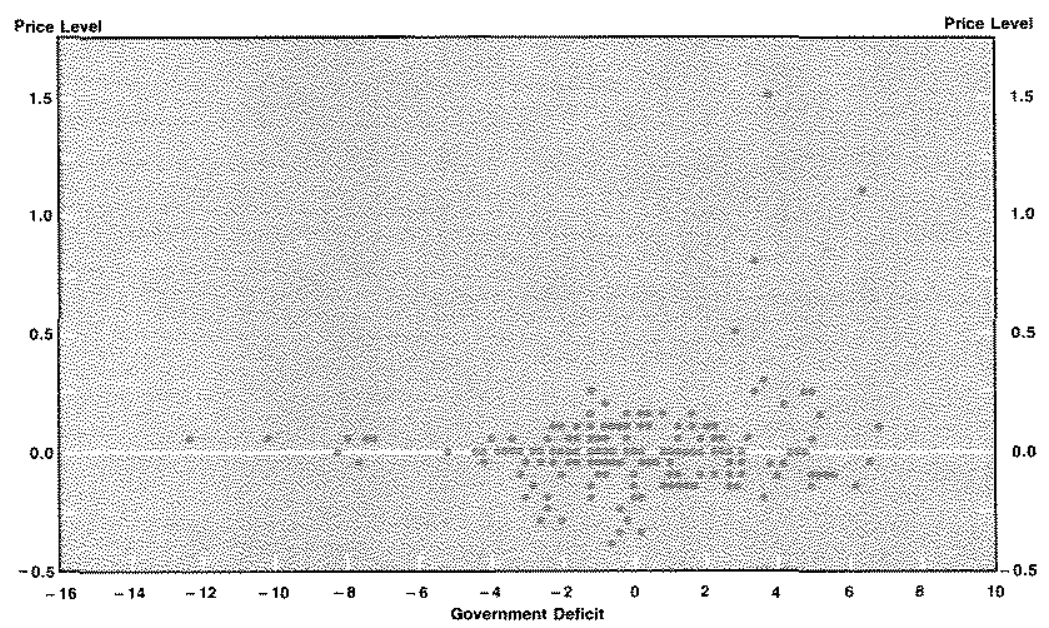




\section{Figure 9}

\section{The Interest Rate and the Government Deficit}

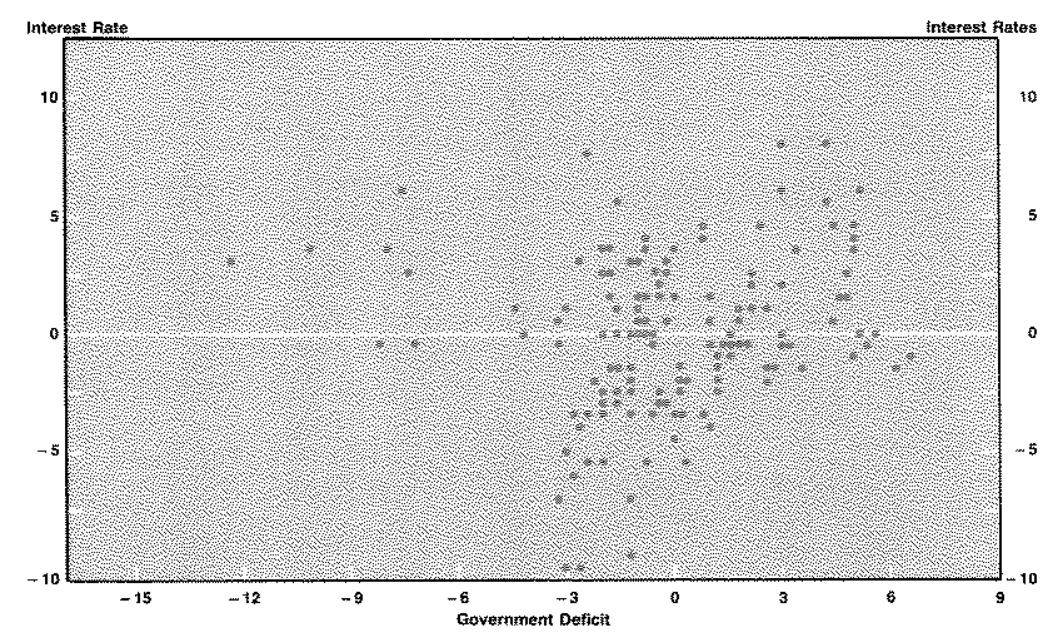

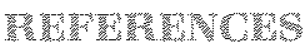

Aschauer, David. "The Equilibrium Approach to Fiscal Policy," Joumal of Money, Credit and Banking (February 1988), pp. 41.62.

"Does Public Capital Crowd Out Private Capital?" Journal of Monetary Economics (September 1989a), pp. $171-88$.

"Is Public Expenditure Productive?" Jounal of Monetary Economics (March 1989b), 177-200.

Barro, Robert J. "The Ricardian Approach to Budget Deficits," Henry Thornton Lecture, City University Business School, London, November 1987.

Bernheim, B. Douglas. "Ricardian Equivalence: An Evaluation of Theory and Evidence," NBER Working Paper No. 2330 (July 1987).

"A Neoclassical Perspective on Budget Deftcits," Journal of Economic Perspectives (Spring 1989), pp. 55-72.

Chrystal, K. Alec, and Daniel L. Thornton. "The Macroeconomic Effects of Defict Spending: A Review" this Review (November/December 1988), pp. 48.60.

Darrat, Ali F. "Fiscal Deficits and Long-Term Interest Rates: Further Evidence from Annual Data," Southern Economic Journal (October 1989), pp. 363-74.

Dewald, Wiliam G., and Michael Ulan. "The Twin-Deficit Illusion," Working Paper No. 90-17, U.S. Department of State, Bureau of Economic and Business Affaiss (February 1990),

Evans, Paul. "Are Consumers Ricardian? Evidence for the United States," Journal of Political Economy (October 1988), pp. 983-1004.

"Interest Rates and Expected Future Budget Deficits in the United Stales," Journal of Political Economy (February 1987), pp. 34-58.

"Is the Dollar High Because of Large Budget Deficits?" Joumal of Monetary Economics (November 1986), pp. 227-49.

Feldstein, Martin, and Dougtas W. Elmendorf, "Government Debi, Government Spending, and Private Sector Behavior
Revisited: Comment," American Economic Review (June 1990), pp. 589-99.

Friedman, Miton. "The Role of Monetary Pollcy," American Economic Review (March 1968), pp. 1-17.

Koray, Faik, and R. Carter Hill. "Money, Debt and Economic Activity," Journal of Macroeconomics (Summer 1988). pp. $351-70$.

Kormendi, Roger, and Philip Meguire. "Government Debt, Government Spending, and Private Sector Behavior: Reply and Update," American Economic Review (June 1990), pp. 604-17.

Laumas, Gurcharan S. "Anticipated Federal Budget Deficits, Monetary Policy and the Rate of Interest," Southern Economic Journal (October 1989), pp. 375-82.

Leiderman, Leonardo, and Assaf Razin. "Testing Ricardian Neutrality with an Intertemporal Stochastic Model," Journal of Money, Credit and Banking (February 1988), pp. 1-21.

McCahtum, Bennett T. "Are Bond-Financed Deficits Inflationary? A Ricardian Analysis," Journal of Political Economy (February 1984), pp. 123-35.

Miller, Presten J, and Thomas J. Sargent. "A Reply to Dar" by," Federal Reserve Bank of Minneapolis Quarterty Review (Spring 1984), pp. 21-26.

Modigliani, Franco, and Arlie G. Sterling. "Government Debt, Government Spending, and Private Sector Behavior: A Futher Comment," American Economic Review (June 1990), pp. 600-03.

Sargent, Thomas J., and Neil Wallace. "Some Unpleasant Monetarist Arithmetic," Federal Reserve Bank of Minneapolis Quarterly Review (Fall 1981), pp. 1-17.

Swamy, Paravastur A. V. B., Bharat R. Kolluri and Rao N. Singamsetti. "What Do Regressions of interest Rates on Deficits Imply?" Southern Economic Journal (April 1990), pp. 1010-28.

Tatom, John A. "U.S. Investment in the 1980s: The Real Story" this Review (MarchiApril 1989), pp. 3-15.

Thomton, Daniel L. "Monetizing the Debi," this Review (December 1984), pp. 30-43. 


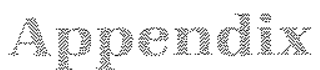

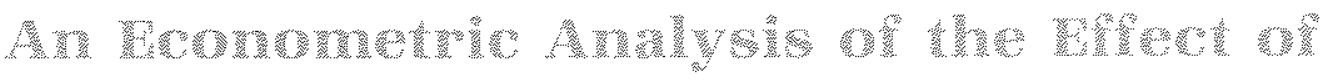

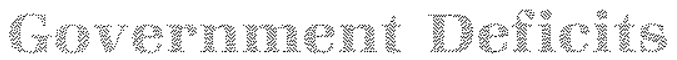

The purpose of this appendix is to see if there is a statistical association between government deficits and some important macroeconomic variables as hypothesized by both the conventional view and the Ricardian alternative.

The analysis begins with the following general equation:

$$
\begin{aligned}
& \text { (A.1) } \mathrm{DV}_{\mathrm{it}}=\alpha_{\mathrm{it}}+\beta_{\mathrm{it}} \mathrm{DEF} \mathrm{F}_{\mathrm{it}}+\varepsilon_{\mathrm{i},} \mathrm{i}=1, \ldots, \mathrm{K} \text {, and } \\
& \mathrm{t}=1, \ldots, \mathrm{T}
\end{aligned}
$$

where $D V_{\mathrm{it}}$ and $D E F_{\mathrm{it}}$ denote the $\mathrm{t}^{\text {th }}$ observation for the $i^{\text {th }}$ country of the dependent variable and the deficit measure, respectively, $\alpha_{i t}$ and $\beta_{i t}$ denote fixed parameters and $\varepsilon_{3 t}$ denotes a random error.

Equation A.1 cannot be estimated because the number of parameters exceeds the number of observations. This problem can be circumvented by obtaining time-series and/or cross-section representations of equation A.1. The time-series representation is obtained by imposing the restrictions $\alpha_{\mathrm{it}}=\alpha_{\mathrm{i}}$ and $\beta_{\mathrm{it}}=\beta_{\mathrm{i}}$ for all $\mathrm{t}$. The cross-sectional representation is obtained by imposing the restrictions $\alpha_{i t}=\alpha_{t}$ and $\beta_{i t}=\beta_{t}$ for all i. These specifications are:

(A.2) $\mathrm{DV}_{\mathrm{it}}=\alpha_{\mathrm{i}}+\beta_{\mathrm{i}} \mathrm{DEF} \mathrm{it}_{\mathrm{it}}+\varepsilon_{\mathrm{it}}$

and

(A.3) $D V_{i f}=\alpha_{\mathrm{t}}+\beta_{\mathrm{t}} \mathrm{DEF} \mathrm{F}_{\mathrm{it}}+\varepsilon_{\mathrm{it}}$.

A pooled time-series/cross-section representation can be obtained by imposing the restric- tions $\alpha_{i t}=\alpha$ and $\beta_{i t}=\beta$ for all $\mathrm{i}$ and $\mathrm{t}$, to obtain

(A.4) $\mathrm{DV}_{\mathrm{it}}=\alpha+\beta \mathrm{DEF} \mathrm{it}_{\mathrm{it}}+\varepsilon_{\mathrm{ir}}$.

(This is equivalent to imposing the restrictions $\alpha_{1}=\alpha$ and $\beta_{i}=\beta$ for all $i$ on the time-series model or $\alpha_{t}=\alpha$ and $\beta_{t}=\beta$ for all $t$ on the cross-sectional model).

Equations A.2-A.4 were estimated with annual observations on the government deficits, nominal interest rate, the trade deficit, the price level $(1980=100)$, the inflation rate, real output growth and private saving for 16 OECD countries $(K=16)$ for which the relevant annual data are available. ${ }^{1}$ The period is from 1975 to 1986 $(\mathrm{T}=12)$. Because the currency-denominated variables are expressed in the respective country's currency, it is necessary to put these data in common units. This was done by measuring these variables as a percent of gross domestic product, GDP. ${ }^{2}$

The equations were estimated both in levels and first-differences. The latter form was estimated because some of the data showed a tendency to trend with time. The sample was too small, however, to perform the usual tests for stationarity. Estimates of first-order autocorrelation from equation A.2 suggest that firstdifferencing may result in over-differencing in many cases. Because some of these data appeared to have trends, the pooled time-series/ cross-section equation, A.4, was estimated by allowing the intercept term to vary with time. ${ }^{3}$ Because the estimates of equations A.2 and A.3
'The interest rate is the three-month money market rate.

${ }^{2}$ This was also done by measuring these variables relative to their mean value for the period and indexing them to 1975. When the variables were normalized in this way, a measure of the level of GDP was also used as a dependent variable. In nearly all cases, estimetes of equations A. 2 and A.3 resulted in insignificant coefficients on the deficit measure, so the results are not reported here.

Also, the OECD data are based on the system of national accounts which differs in a number of respects from our system of national income and product accounts. One of these is that capital expenditures by government are not treated as current expenditures, so that the deficit is current expenditures plus consumption of fixed capital less revenue.
TThe reported intercepts in tables A.1 and A,2 are for 1986. The equations were also estimated using a time trend. The results with this variable were not qualitatively different from those that allowed for a time-varying intercept. Consequently, they are not reported here. Also, the equations were estimated using the alternative dependent variables as regressors. Except for the interest rate, however, the qualitative results were unaffected, so these results are not presented here. 
are qualitatively the same as those of equation A.4, only estimates of equation A.4 are presented.

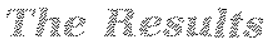

Estimates of equation A.4 for both levels and first-differences are reported in table A.1. The only coefficients that are statisticaliy significant in both the level and first-difference specifications occur when the trade deficit or private saving is the dependent variable. In the latter case, however, the coefficient was negative, which suggests that increases in deficit spending are associated with decreases in personal sav. ing: when public saving decreases, so does private saving. This result is not consistent with the Ricardian view that public and private saving are substitutes; however, it might reflect an endogenous response of both government deficits and personal saving to cyclical variations in output. It is well-known that deficits tend to rise relative to GDP when output falls. Likewise it might be that personal saving also rises when output falls, as individuals try to maintain their level of consumption in the wake of declining income levels. In this case, personal saving would decline relative to GDP. The simultaneous response of both government deficits and personal saving to cyclical variation in income could account for the statistically significant negative coefficient on the deficit when personal saving is the dependent variable.

Barro (1987) also found a positive and statistically significant relationship between the two deficits using U.S. data, but stated that this relationship emerges only when data for the 1980s were included. When the sample was partitioned into $1975-80$ and $1981-86$ periods, a positive relationship emerged between the twin deficits during both periods; however, consistent with the findings of Barro, the relationship was not statistically significant during the first period. ${ }^{3}$

Dewald and Utan (1990) argue that the positive relationship between the twin deficits in the U.S. results from failing to account for inflation or changes in the market value of the net U.S. federal debt or other major elements of the
U.S. external wealth position. When adjustments for these factors are made $e_{f}$ they find no statistically significant relationship between the two deficits. Because this argument might apply to cross-sectional data as well, caution should be used in interpreting these results as evidence of the conventional wisdom on the twin deficits. This is especially true because the estimated coefficient on the deficit is not large: a 1 percentage-point rise in the government defict relative to GDP would result in only about a .20 percentage point rise in the trade deficit relative to GDP. Moreover, as shown later, the result is not robust.

The statistical significance of the coefficient on the deficit when inflation or the price level is the dependent variable depends on whether the equation is estimated in levels or firstdifferences, being insignificant in the former case and significant in the latter. In either case, however, the coefficient has a sign opposite that of the conventional story. Consequently, these results are not evidence for or against either of these views.

The same result occurs when the growth rate of GDP is the dependent variable. In this case, however, the conventional wisdom does not state the direction of the expected change. From a shortrun perspective, output growth should be positively related to deficits. From a longrun perspective, they should be negatively related. The results in table A.1 suggest a positive relationship if first differences are used, with a 1 percentage-point increase in the deficit being associated with a quarter of a percent increase in the rate of growth of GDP. Of course, if the increase in the deficit is due to an increase in government spending, there is a positive rela. tionship between deficits and GDP by definition, if crowding out is not complete.

Estimates of the effect of the deficit on interest rates also are sensitive to the specification of the equation. When levels are used, there is a negative, but statistically insignificant, relationship between interest rates and the deficit. When first-differences are used, however, there is a positive and statistically significant la one-

statistic of 1.42. The comparable statistics for the second period are .307 and 3.52 , respectively. The same statistics for the two periods for the first-difference specification are .094 and 1.37 and .226 and 3.01 , respectively.

\footnotetext{
It was assumed that variance was constant over time, but differed over cross-sections, that is, $E\left(\varepsilon_{i \mathrm{i}} \varepsilon_{j}\right)=\sigma^{2}{ }_{i}$ for $\mathrm{i}=\mathrm{j}$ and $t=s$ and 0 otherwise. Estimates of equation $A .2$ in dicated considerable cross-sectional heteroskedasticity.

5The estimated coefficient on the deficit variable during the first period for the level specification was .181, with a :-
} 
Table A.1

Pooled Time-Series, Cross-Sectional Estimates of Equation A.4

\begin{tabular}{|c|c|c|c|c|}
\hline \multirow[b]{2}{*}{$\begin{array}{l}\text { Dependent } \\
\text { variable }\end{array}$} & \multicolumn{2}{|c|}{ Levels } & \multicolumn{2}{|c|}{ First difference } \\
\hline & constant & $\begin{array}{l}\text { Deficit } \\
\text { measure }\end{array}$ & Constant & $\begin{array}{l}\text { Deticit } \\
\text { measure }\end{array}$ \\
\hline Trade deflolt & $(2,39)^{\circ}$ & $\begin{array}{l}0.195 \\
(242)\end{array}$ & $\begin{array}{l}0.453 \\
(1.43)\end{array}$ & $\begin{array}{l}0,127 \% \\
(226)\end{array}$ \\
\hline Personal saving & $\begin{array}{c}9163^{\circ} \\
(1425)^{\circ}\end{array}$ & $\begin{array}{l}-0.447 \\
(6.59)\end{array}$ & $\begin{array}{l}0.97 \\
(077)\end{array}$ & $\left(0,170^{\circ}\right.$ \\
\hline Output growth & $\frac{2349}{(5.67)}$ & $\begin{array}{r}-0.060 \\
(134)\end{array}$ & $\frac{1,200^{\circ}}{(2.87)}$ & $\begin{array}{l}0,244 \\
(373)\end{array}$ \\
\hline Intation & $4(5,76)^{\circ}$ & $\begin{array}{l}-0.061 \\
0.77\end{array}$ & $(0.327$ & $8(4,40)$ \\
\hline Price level & $(7544)$ & $\begin{array}{r}-0,002 \\
1,171\end{array}$ & $\begin{array}{c}0.07 \\
(12,11\end{array}$ & $\frac{-0.004}{(3.58)}$ \\
\hline Interest rate & $\begin{array}{l}8.120^{\circ} \\
(10.89)\end{array}$ & $\begin{array}{l}-0.020 \\
(0.28)\end{array}$ & $\begin{array}{r}-0.886 \\
(1.96)\end{array}$ & $\begin{array}{l}0.248 \\
(1.95)\end{array}$ \\
\hline
\end{tabular}

indicates statistical signiticance at the 5 percent level.

tailed test at the 5 percent significance level) relationship between the two variables. Even if one takes the results that are most supportive of the conventional wisdom, however, the effect of deficits on interest rates is fairly weak: a 1 percentage-point rise in the deficit relative to GDP is estimated to produce about a 25 basispoint rise in nominal interest rates.

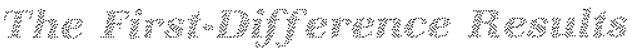

While the results for the first-difference specification appear to indicate statistically significant relationships between the government deficit and all of the dependent variables, these relationships are not as strong as the results in table A.1 would suggest. Scatter plots of the first-differenced data, mean-adjusted, are presented in figures A.1-A.6. These data suggest that much of the reported statistically significant relationship could be due to a relatively few outliers. In most cases, these are attributable to two countries, Greece and Norway. Also, the reported results could be due to the failure to account for other factors that affect the relevant dependent variable. Both issues are investigated in table A.2, which reports the results of estimates of the first-difference specification when Greece and Norway are deleted and, alternatively, when all other variables are included as regressors. ${ }^{6}$ As the table shows, the results are sensitive to both of these changes. Deficits are not significantly related to the price level or interest rates when the two countries are deleted and no longer have a statistically significant effect on the trade deficit, the price level or the interest rate when the other variables are included. The only significant effects that are robust to these changes are those for the effect of the deficit on private saving, output growth and inflation. In the first and last case, however, the sign of the coefficient is opposite that suggested by the conventional view.

EAll other variables save the interest rate, since the interest rate was unavailable for Austria, Canada, Finland and Greece. 
Figure A1

Change in The Trade Deficit and the Government Deficit

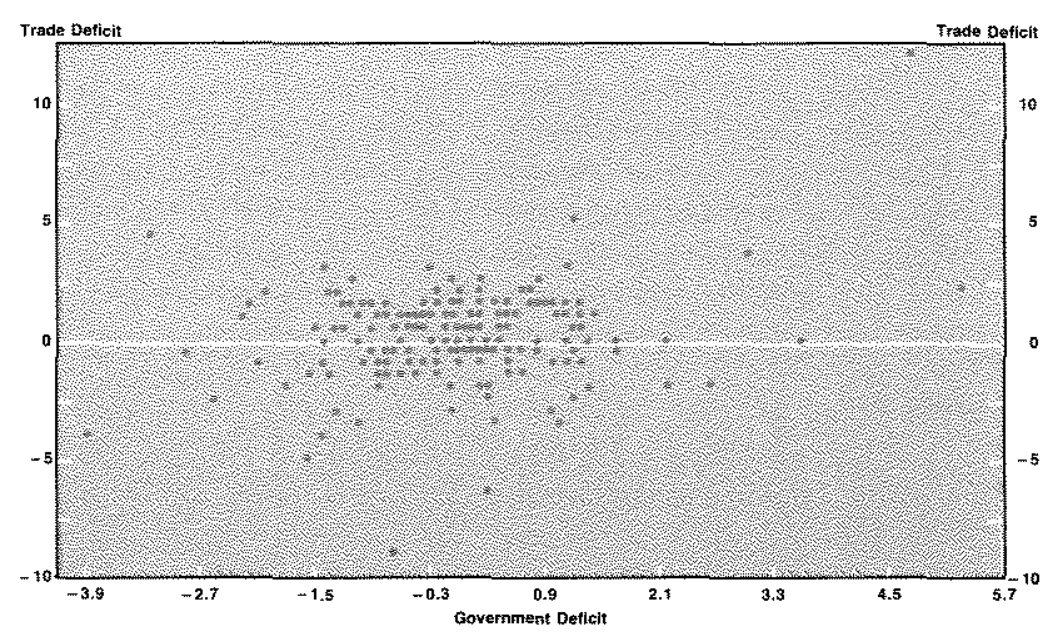

Figure A2

Change in Personal Saving and the Government Deficit

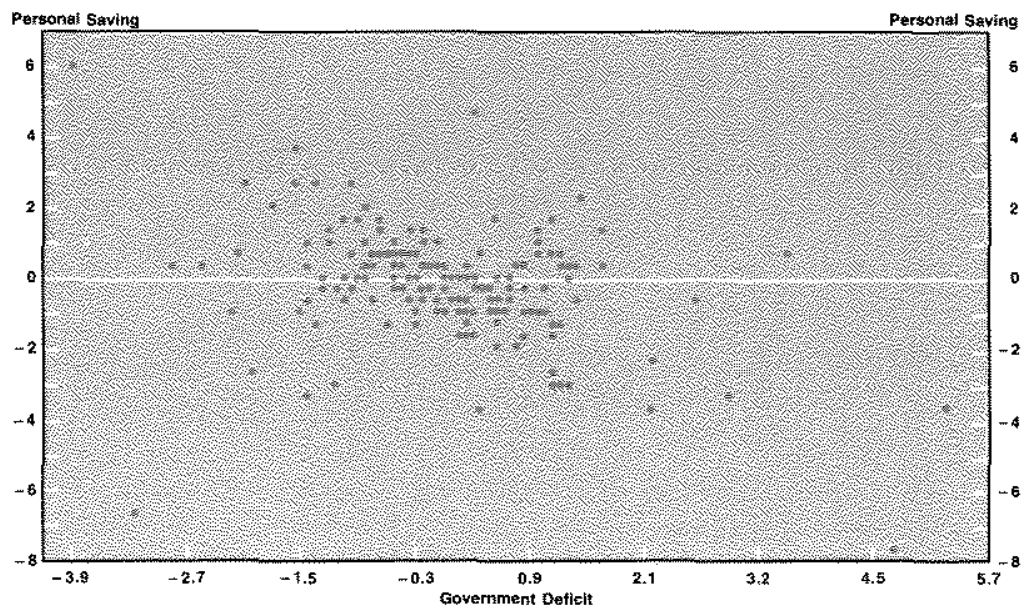

Figure $\mathrm{A} 3$

Change in the Inflation Rate and the Government Deficit

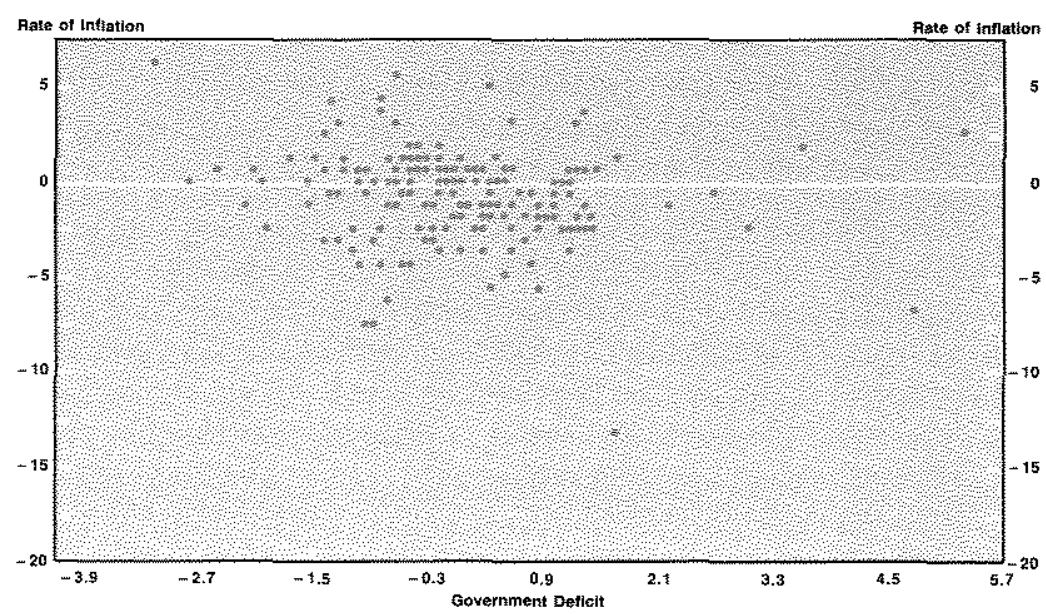




\section{Figure A4}

Change in the Growth Rate of Real GDP and the

Government Deficit

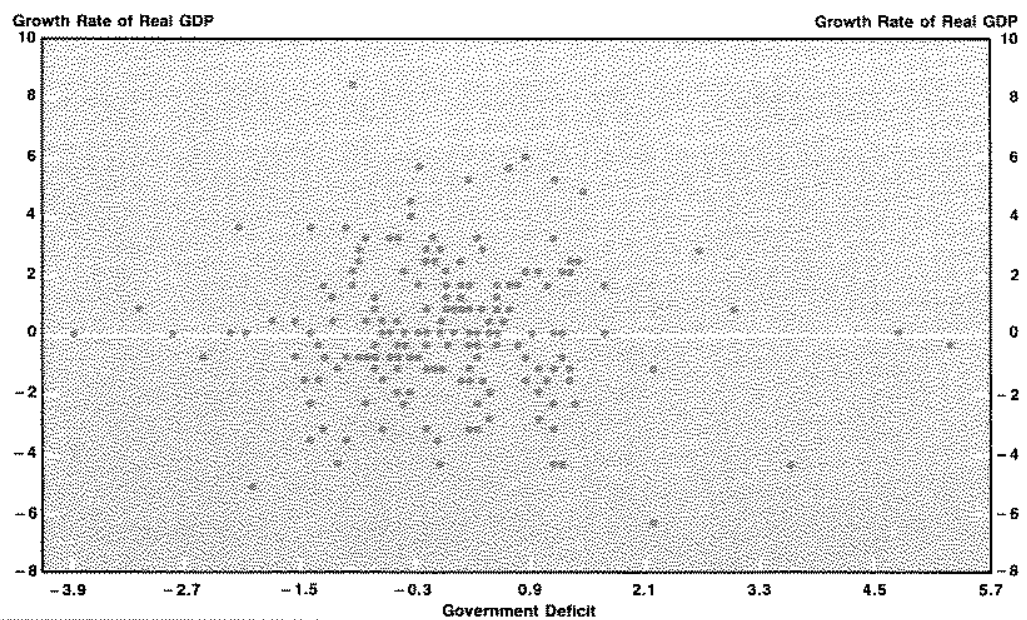

\section{Figure A5}

Change in the Price Level and the Government Deficit

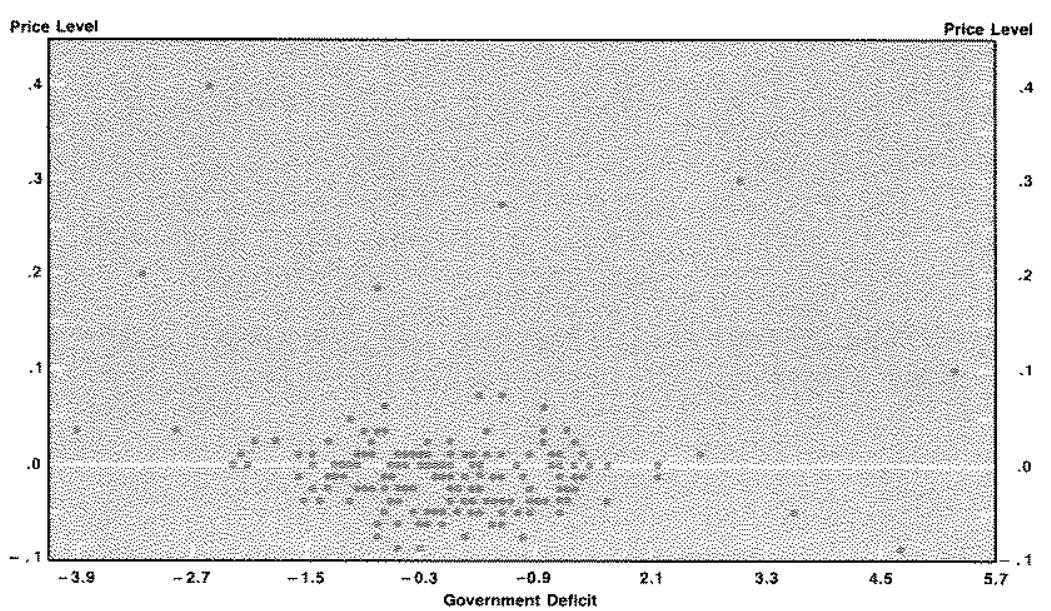

T2.

Figure A6

Change in the Interest Rate and the Government Deficit

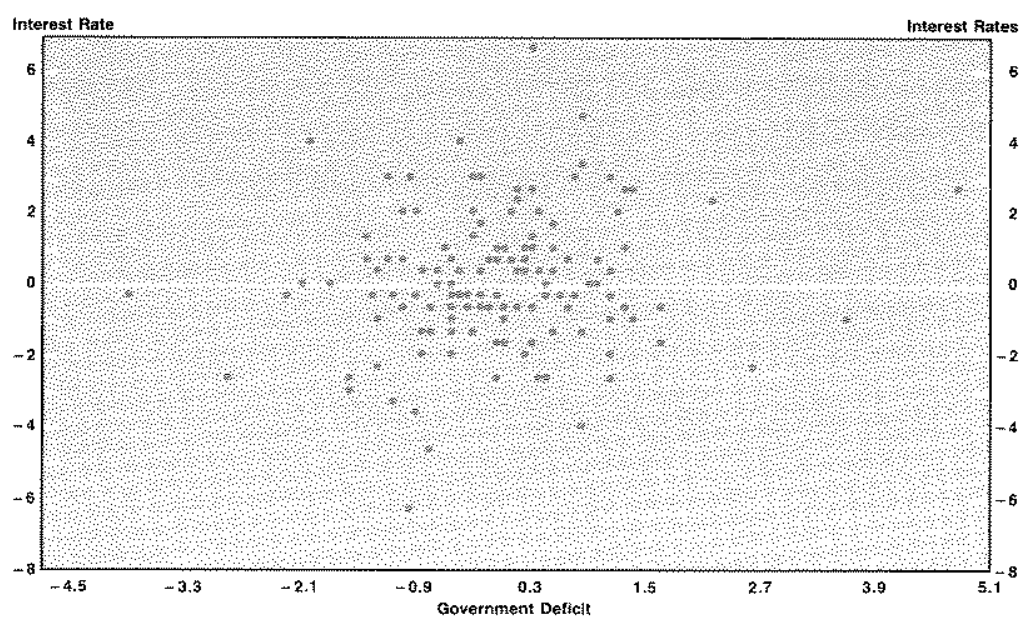


Table A. 2

Estimates of Two Alternative First-Difference Specifications

\begin{tabular}{|c|c|c|c|c|}
\hline \multirow[b]{2}{*}{$\begin{array}{l}\text { Dependent } \\
\text { variable }\end{array}$} & \multicolumn{2}{|c|}{$\begin{array}{l}\text { Greece and } \\
\text { Norway deleted }\end{array}$} & \multicolumn{2}{|c|}{$\begin{array}{l}\text { All alternative dependent } \\
\text { vartables ncluded }\end{array}$} \\
\hline & Constant & $\begin{array}{l}\text { Deficit } \\
\text { variable }\end{array}$ & Constant & $\begin{array}{l}\text { Deficit } \\
\text { vartable }\end{array}$ \\
\hline Trade defict & $\begin{array}{l}-0.611^{+} \\
(2.03)\end{array}$ & $0.128^{\circ}$ & 0.072 & $\begin{array}{r}-0.013 \\
(0.23)\end{array}$ \\
\hline Personal saving & $\begin{array}{r}0.312 \\
(1 \times 28)\end{array}$ & $\begin{array}{r}-0,143^{*} \\
(297)\end{array}$ & $\begin{array}{r}0.400 \\
(1.63)\end{array}$ & $\begin{array}{l}0.213 \\
(455)\end{array}$ \\
\hline Output growth & $\frac{-1.056^{*}}{(231)}$ & $\begin{array}{l}0,342^{\circ} \\
(4.01)\end{array}$ & $\begin{array}{l}-0.930 \\
(2,26)\end{array}$ & $\frac{0,330^{\circ}}{(466)}$ \\
\hline Inflation & $\begin{array}{l}0.378 \\
(1.94)\end{array}$ & $\begin{array}{l}0.126^{*} \\
(365)\end{array}$ & $\begin{array}{l}0.112 \\
(0.54)\end{array}$ & $\frac{0.093^{*}}{(2.63)}$ \\
\hline Price level & $\begin{array}{l}0.051 \\
(7.91)\end{array}$ & $\begin{array}{r}-0.002 \\
(1.73)\end{array}$ & $\begin{array}{l}0.062 \\
(8.81)\end{array}$ & $\begin{array}{r}-0.001 \\
(0.95)\end{array}$ \\
\hline Interest rate & $\frac{-1.093}{(2.29)}$ & $\begin{array}{l}0.128 \\
(0.78)\end{array}$ & $\begin{array}{l}-0.934 \\
(1.95)\end{array}$ & $\begin{array}{l}0.090 \\
(0.61)\end{array}$ \\
\hline
\end{tabular}

Indicates statistical significance at the 5 percent level. 